\title{
An Investigation of the Irish Ray Fishery in ICES Divisions VIIa and VIIg
}

\author{
M. J. Gallagher, F. Jeal and C. P. Nolan \\ Zoology Department, Trinity College \\ Dublin 2, Ireland
}

Gallagher, M. J., F. Jeal, and C. P. Nolan. 2005. An investigation of the Irish ray fishery in ICES divisions VIIa and VIIg. J. Northw. Atl. Fish. Sci., 35: 1-13. doi: 10.2960/J.v35.m508

\begin{abstract}
A study of the mixed-species ray fishery off the east and southeast coast of Ireland was carried out between 1997 and 1998, which involved port sampling and collection of commercial transactions data and official logbook data. Several years of commercial transactions data collected allowed seasonal trends in the relative abundance of the commercial size grades to be deciphered. Catch composition by species and sex was determined for the entire ray landings of individual vessels in the fishery during each port sampling occasion. Biological data were collected from 17450 rays during 1997 and these data were used to reconstruct the size and age structure of the population at the species level. Each species had a narrow age distribution, generally ranging from 2 to 8 years. Total mortality estimates $\left(Z^{1}\right)$ derived from catch curves were high, ranging from 0.456 for female Raja brachyura to 1.110 for male Raja montagui, but were generally lower than the total instantaneous mortality derived, with the exception of male $R$. montagui $\left(Z^{1}=0.813\right)$. Demographic analysis, using life tables, revealed that, with the exception $R$. montagui $(r=-0.045)$, each of the commercial species had positive population growth, ranging from $r=0.125$ for $R$. clavata to $r=0.224$ for $R$. brachyura. The results of the analyses are discussed with respect to previous studies and observed trends in the fishery.
\end{abstract}

Key words: age, fishery, Ireland, logbook, population, rays, sampling

\section{Introduction}

The Irish Sea ray (family Rajidae) fishery is one of the longest established and most commercially important ray fisheries in the Northeast Atlantic (Brander, 1988; Fahy, 1989). UK vessels have been the traditional exploiters, landing between 5000 and 6000 tons annually between 1920 and 1940 (Holden, 1977). Following the demise of the UK fleet, landings dropped proportionally and Irish whitefish trawlers have become the main prosecutor of the fishery, with rays providing both a regular by-catch and seasonally directed resource of up to 2000 tons annually over the past two decades (Fahy, 1989; Hillis and Grainger, 1990). With the decline of traditional teleost species and associated restrictive quotas, the relative importance of this non-quota ray fishery has further increased (Anon., 1999a).

Given the conventional susceptibility of elasmobranchs to over-exploitation, concerns have long been expressed over the sustainability of this resource (Steven, 1936; Holden, 1977; Brander, 1981; Fahy, 1989). Despite this, few studies have focussed on directly assessing this fishery and the conclusions drawn regarding the status of its commercial species remain tentative (Holden, 1977; Brander, 1988; Fahy, 1989). It has, however, been widely acknowledged that the fishery is under pressure, with the effects of long-term exploitation clearly evident. This is epitomized by the commercial extinction of the common skate Raja batis (Brander, 1981) and the localized depletion and decline in the abundance, and size distribution, of the commercially important thornback ray, Raja clavata (Fahy, 1989; Dulvy et al., 2000).

Within the European Union, co-ordinated sampling programmes exist for the majority of the commercially exploited whitefish species, in order to facilitate stock assessments and quota determination (e.g. total allowable catches) (ICES, MS 1998; Anon., 1999b). However a combination of limited resources being afforded to elasmobranch research and the difficulties encountered in sampling to determine species-specific population structures from mixed species landings has resulted in irregular and inconsistent assessments being carried out on this commercially important group. As a result, few conclusions can be drawn on the historical or current status of the stocks.

The commercial grading systems in place for ray landings were described in recent studies of the Irish ray fishery in the western Irish Sea and off the south east coast of Ireland (Fahy, 1989; 1991). The three main grades that are in use in these fisheries are large, medium, and small, and it is within these grades that the commercial species 
are placed, based mainly on their size (Fahy, 1989). From these studies it was suggested that it should be possible to derive the population structure of the ray landings at the species level if sampling was carried out within the commercial grades.

This study set out to develop and implement a sampling programme for the Irish ray fishery in the Irish Sea (ICES Division VIIa) and off the south east coast of Ireland (VIIg), and to collect and utilize available data from the fishery to establish the population structure by species and characterize the fishery.

\section{Methods}

\section{Port sampling}

Following a preliminary investigation of the fishery, a sampling program was initiated in the first quarter of 1997. Howth, Arklow and Kilmore Quay (Fig. 1) were chosen as the main port sampling locations as they represented the largest ray landing locations in ICES Divisions VIIa and VIIg (source: Department of Communications, Marine and Natural Resources, Ireland). At each port, the landed catches were laid out by vessel and by species, which facilitated rapid sampling. During each sampling trip, and prior to the measurement of the catch, the name of the vessel, gear type, date of sampling, other species caught, and the area fished (ICES Division and Statistical Rectangle) were noted. Each sampled ray was identified to species, sexed and measured (total length) to the nearest centimetre below. Each box of fish was graded in accordance with the commercial grading system at each sampling location, with the port handlers verifying the grade assigned when required. During sampling, the contents of each box of ray were recorded separately along with their associated commercial size grade in order to establish the species composition and size ranges of the commercial grades. The gutted weights of sampled specimens were also recorded, on three separate sampling occasions, in order to derive length weight relationships. On some sampling trips, port-handling dockets were available for the sampled fish boxes, detailing the net weight of the box contents and the associated commercial grade. With the exception of one occasion, the total landed catch from a single vessel was measured during a sampling trip. In total 17450 fish were sampled during the port sampling programme in 1997.

\section{Data acquisition}

Between two and four years of daily commercial transactions data were acquired from each of the port sampling locations. These data consisted of the weight of each box of ray sold, its associated commercial grade and unit value.

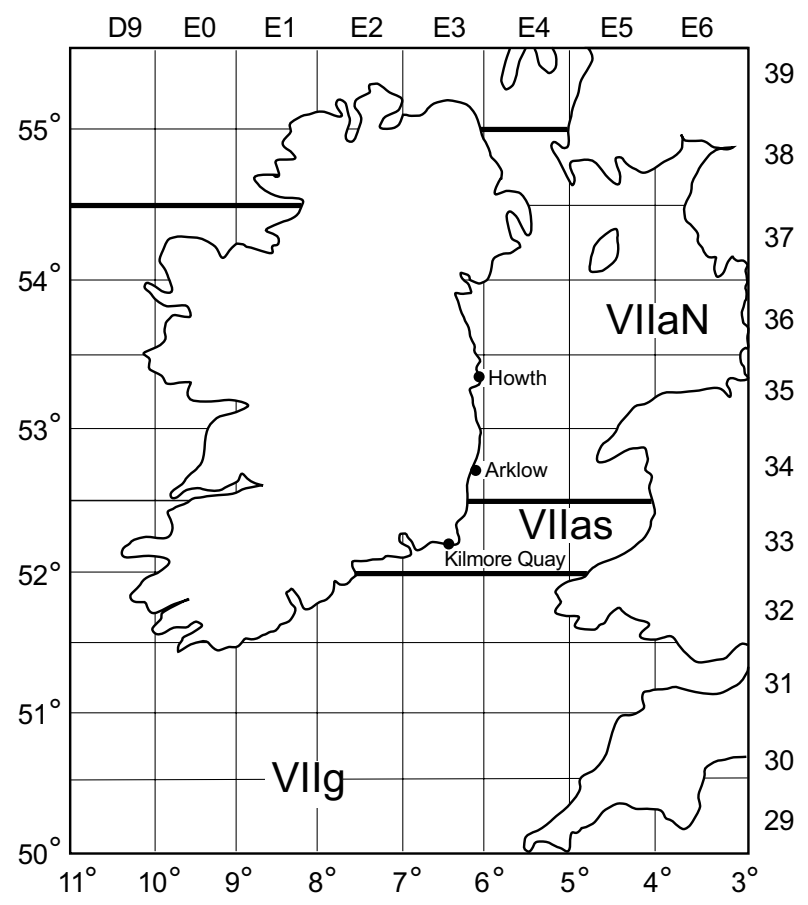

Fig. 1. Map of ICES Div. VIIa and VIIg, with ICES Statistical Rectangles, and port sampling locations included. 
Proforma submissions in the European Communities (EC) logbook for all Irish vessels recording ray landings in ICES Divisions VIIa and VIIg were obtained from the Department of Communications, Marine and Natural Resources, Ireland, for 1995, 1996 and 1997. These daily records included date, gear type, fishing location (Statistical Rectangle fished), effort (hours fished), number of 45 $\mathrm{kg}$ fish boxes of rays landed and port landing location. For the purposes of confidentiality, vessel names were omitted from the records. Data on the size (gross registered tonnage) and power (kilowatts (kw)) of vessels were only obtained for vessels in 1997.

\section{Data analysis}

Using the data acquired, the following analyses were conducted:

- Annual ray landings by area (VIIa and VIIg) and port sampling location (official logbook data)

- Monthly ray landings from VIIa and VIIg (official logbook data)

- Annual ray landings by gear type (official logbook data)

- Annual ray landings by Statistical Rectangle (official logbook data)

- Monthly effort, landings and landings per unit effort for VIIa (official logbook data)

- Assessment of the reliability of logbook data (official logbook data and commercial landings data).

- Assessment of the seasonality of the directed ray fishery (official logbook data and commercial landings data).

\section{Size and age structure of the commercial ray species}

The population structure of the commercial landings for each of the ray species was reconstructed using a somewhat similar methodology to that used on the commercial teleost species in European Community waters (ICES, MS 1998). This method essentially involves raising the sampled landings by quarter to the official quarterly landings using length weight conversions. Although this process is more involved for rays, owing to the fact that they are landed as a mixed-species assemblage, sampling within each of the main commercial grades, and raising each sampled grade to the graded commercial landings, prior to raising the data up to the official logbook data, ensures that each of the grades are not misrepresented in the raised landings. The raised size distributions for each quarter were combined to obtain the total, raised, size distribution for each species, by sex in 1997. These were then converted to age distributions using age-length keys derived from length-at-age data (Gallagher et al., 2004).

\section{Mortality and demography}

Total instantaneous mortality coefficients $(Z)$ were derived for each species, by sex, by logging the catch numbers-at-age from the raised age distributions and fitting a regression to the descending limb of the distribution. Natural mortality estimates for each species were derived using Pauly's equation (Pauly, 1980), which is given by:

$$
\begin{gathered}
\ln (M)=-0.0152-0.279 \ln \left(L_{\infty}\right)+ \\
0.6543 \ln (K)+0.463 \ln (T)
\end{gathered}
$$

where $l n=$ natural logarithms; von Bertalanffy growth parameters $\left(L_{\infty}\right)=$ maximum theoretical size attained; $K=$ rate at which maximum theoretical size is attained); $T=$ annual mean surface seawater temperature (data logger temperature from Zoology Department, Trinity College Dublin, Ireland). Growth parameters were obtained from Gallagher et al., 2004.

Replacement mortality estimates were derived for each species using Holden's (1974) equation; $Z=x e^{-Z t m}$; where $x=$ the average number of female young produced per year, $t m=$ age at $50 \%$ maturity, $Z=$ total instantaneous mortality coefficient, $Z=$ replacement mortality coefficient. Annual fecundity estimates derived from Walker and Hislop's (1998) study were used (blonde ray 65, thornback ray 50, spotted ray 42 and cuckoo ray 45 eggs laid per year). Age-at-maturity estimates were obtained from Gallagher et al. (in prep.) and total instantaneous mortality coefficients $(Z)$ were derived from the logged catch number-at-age derived above.

Life tables were used to derive the instantaneous growth rate $(r)$, generation time ( $G$, years), and multiplication rate per generation $\left(R_{0}\right)$ for each species. The total instantaneous mortality $(Z)$ and the age-at-maturity obtained from Gallagher et al. (in prep.) were used as input parameters for the natural survivorship function $\left(\left(l \mathrm{x}=N_{0}\left(\mathrm{e}^{-(\mathrm{Z})(\mathrm{t})}\right)\right.\right.$, where $Z=$ total mortality, and $t=$ age at $50 \%$ maturity).

\section{Results}

Analysis of the official logbook data allowed a wide variety of aspects of the fishery to be characterized, including:

- The establishment of the importance of each port sampling location (Fig. 2) and gear type (Fig. 3) in terms of ray landings,

- Determining trends in monthly landings of rays (Fig. 4), 


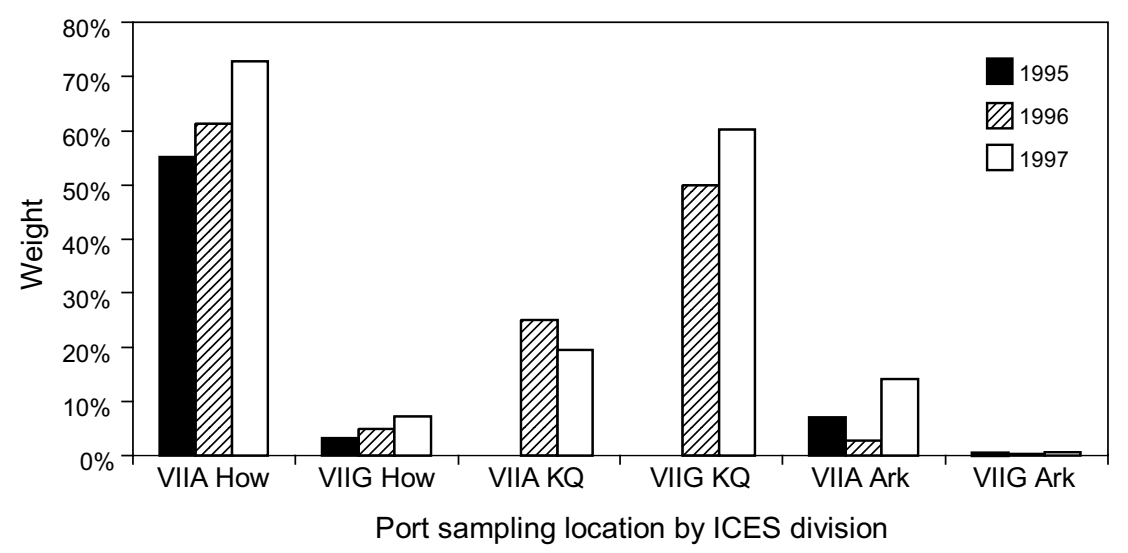

Fig. 2. Percentage (weight) of total Irish annual ray landings from ICES Divisions VIIa and VIIg landed at each port sampling location in 1995, 1996 and 1997. Source: (Dept. of Communications, Marine and Natural Resources, Ireland). Note; VIIA How, VIIA KQ, VIIA Ark = percent weight of total ray landings from VIIa landed at Howth, Kilmore Quay and Arklow, respectively. VIIG How, VIIG KQ, VIIG Ark = percent weight of total ray landings from VIIg landed at Howth, Kilmore Quay and Arklow, respectively.

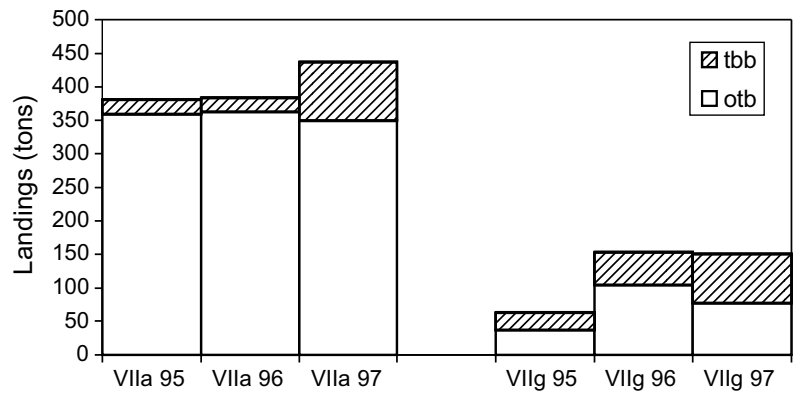

Fig. 3. Annual ray landings of the Irish fleet, by gear type, from ICES Divisions VIIa and VIIg from 1995 to 1997. (Note: otb = otter trawler; tbb = beam trawler; VIIa 95, VIIa 96, VIIa 97 = ICES Division VIIa in 1995, 1996, and 1997; VIIg 95, VIIg 96, VIIg 97= ICES Division VIIg in 1995, 1996, and 1997) Source: (Dept. of Communications, Marine and Natural Resources, Ireland).

- Describing the spatial distribution of ray landings (Fig. 5-8),

and

- Comparing monthly effort, landings and yield of rays by ICES Division (Fig. 9).

A more detailed description of the analyses of the commercial ray landings and logbook data is given in Gallagher (2000).

A consistent trend between monthly landings from official logbook data and commercial landings data was evident for both port-sampling locations (Fig. 9 and 10).
The seasonality of the directed ray fishery in Statistical Rectangle 35E4 was clearly evident when the monthly proportions of the large ray grade from the commercial landings and effort of otter trawlers in 35E4 were plotted together (Fig. 11).

Length-frequency distributions of the sampled ray landings by species and sex presented (Fig. 12 a-d) illustrate that the larger male rays were more abundant than females for both blonde and cuckoo rays.

\section{Raised age distributions by species and sex}

Apart from a small peak evident between 7 and 9 yrs for the larger-sized blonde and thornback rays, all four species had similarly shaped age distributions (Fig. 13 a-d), with the majority of the population between 3 and 4 yrs. The exception was for female thornback ray, where the maximum number-at-age occurred at $5 \mathrm{yrs}$.

Male cuckoo and blonde rays were the most abundant species, with an estimated total of 156592 and 127 825 specimens landed respectively from areas VIIa and VIIg in 1997 (Table 1). Apart from the spotted ray, males were more abundant than females for each species. The thornback ray was the least abundant of the four main commercial species sampled, with just over 18000 specimens landed.

\section{Mortality and demography}

Total mortality $(Z)$ estimates revealed that the smallersized species had the highest mortality levels (e.g. male, 


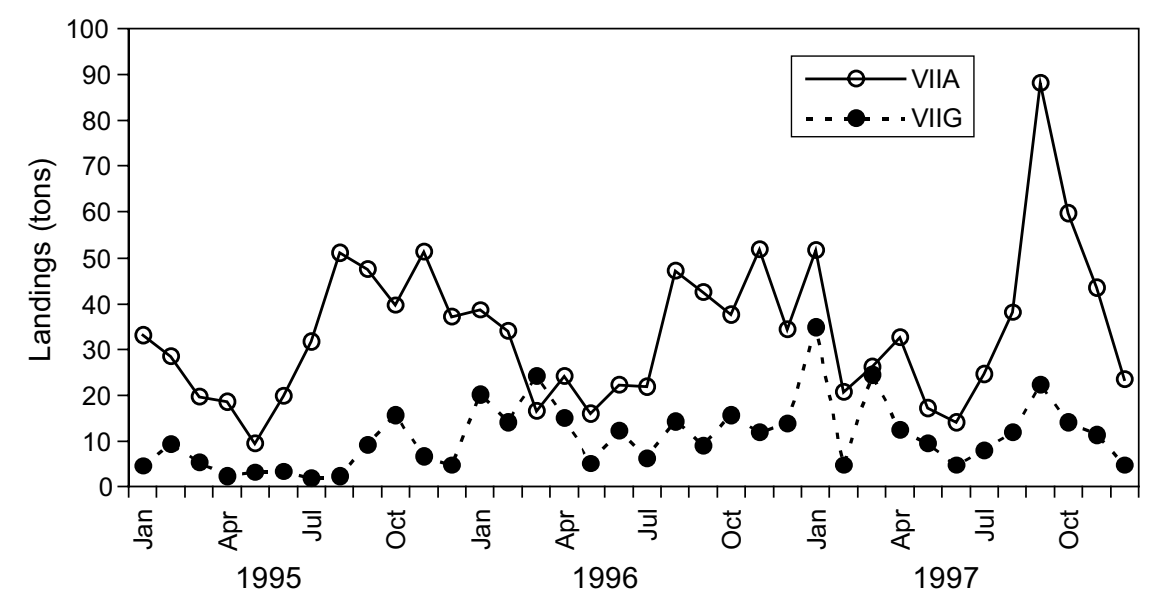

Fig. 4. Trends in monthly Irish ray landings from 1995 to 1997 for ICES Divisions VIIa and VIIg Source: (Dept. of Communications, Marine and Natural Resources, Ireland).

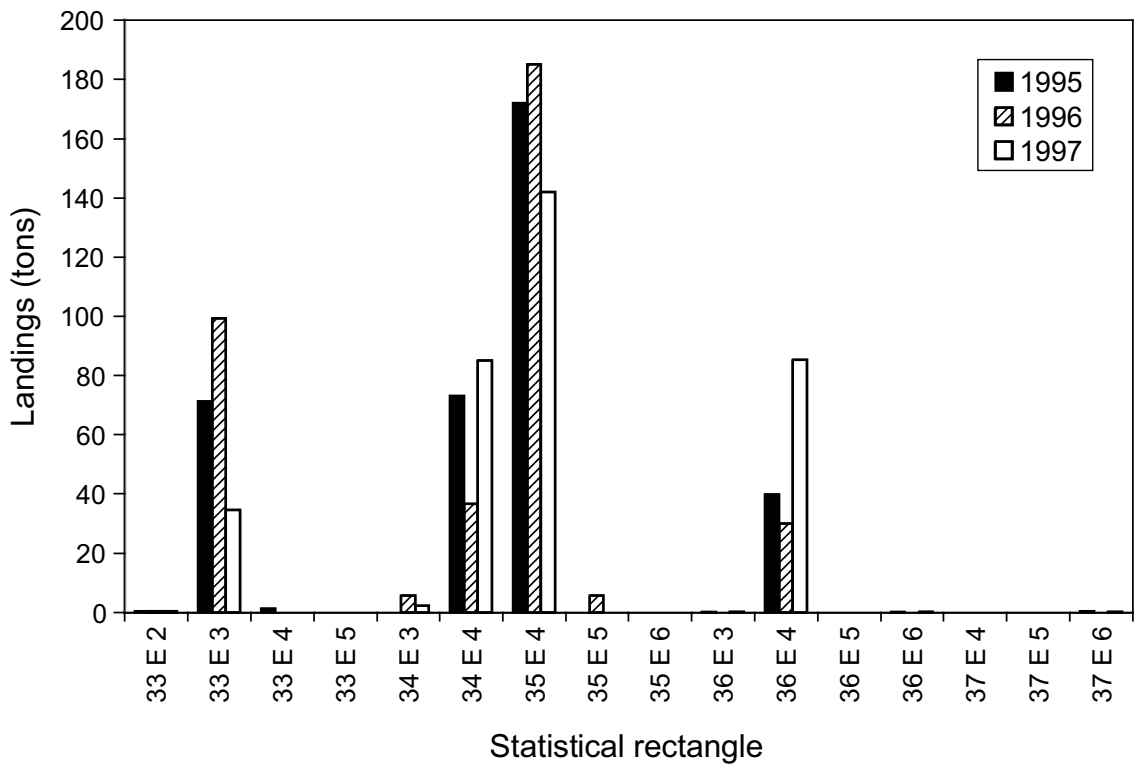

Fig.5. Total ray landings by statistical rectangle for the Irish otter trawler fleet recording ray landings in ICES Division VIIa. Source: (Dept. of Communications, Marine and Natural Resources, Ireland).

spotted ray $Z=1.11$ ) (Table 1), whereas lower mortalities were evident for the larger-sized species (e.g. female, blonde ray; $Z=0.456)$. In addition, higher and lower natural mortality $(M)$ estimates were also evident for the smaller and larger-sized species (e.g. male, spotted ray; $M=0.433$, female thornback ray; $M=0.166$ ). Fishing mortality estimates $(F=\mathrm{Z}-\mathrm{M})$ revealed that with the exception of male spotted ray, which exhibited a fishing mortality of 0.677 , most of the ray species assessed experienced fishing mortalities between 0.4 and 0.6 .
Replacement mortality $\left(Z^{\prime}\right)$ estimates, in which parameters of age-at-maturity and fecundity are used in the determination, revealed that replacement mortality estimates were higher than total mortality estimates for all species, except for male, spotted ray $(Z=0.813, Z=$ 1.11) (Table 2).

Of the smaller-sized species, there was a higher proportion of mature males in the spotted rays than in other species in the combined landings from VIIa and VIIg in 


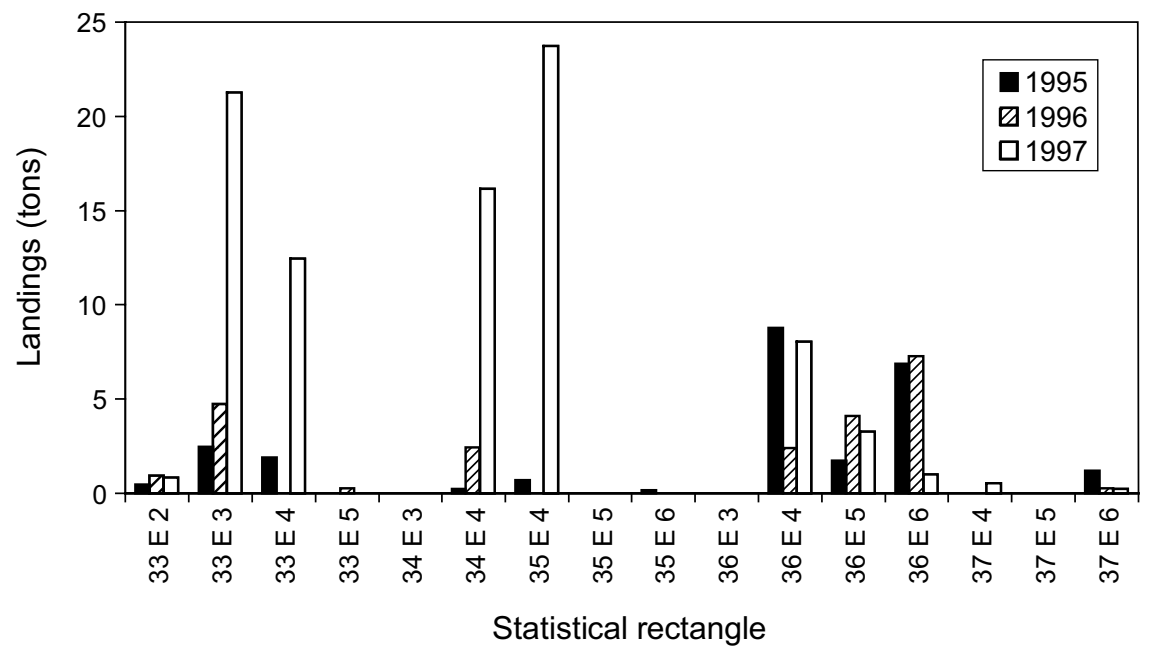

Fig.6. Total ray landings by statistical rectangle for the Irish beam trawler fleet recording ray landings in ICES Division VIIa. Source: (Dept. of Communications, Marine and Natural Resources, Ireland).

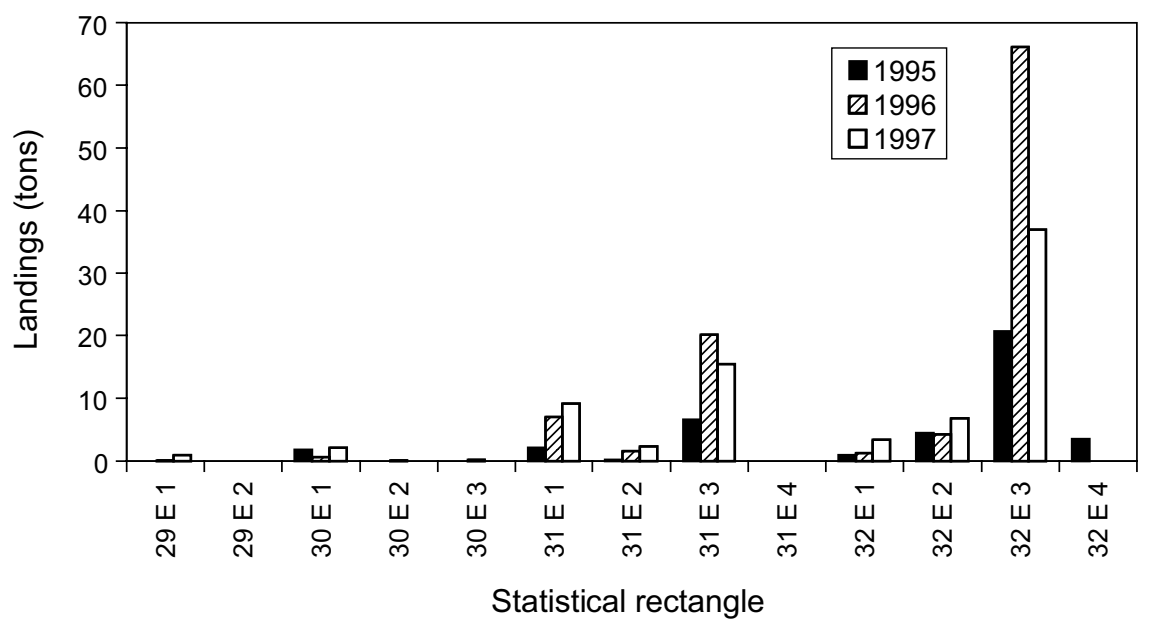

Fig. 7. Total ray landings by statistical rectangle for the Irish otter trawler fleet recording ray landings in ICES Division VIIg. Source: (Dept. of Communications, Marine and Natural Resources, Ireland).

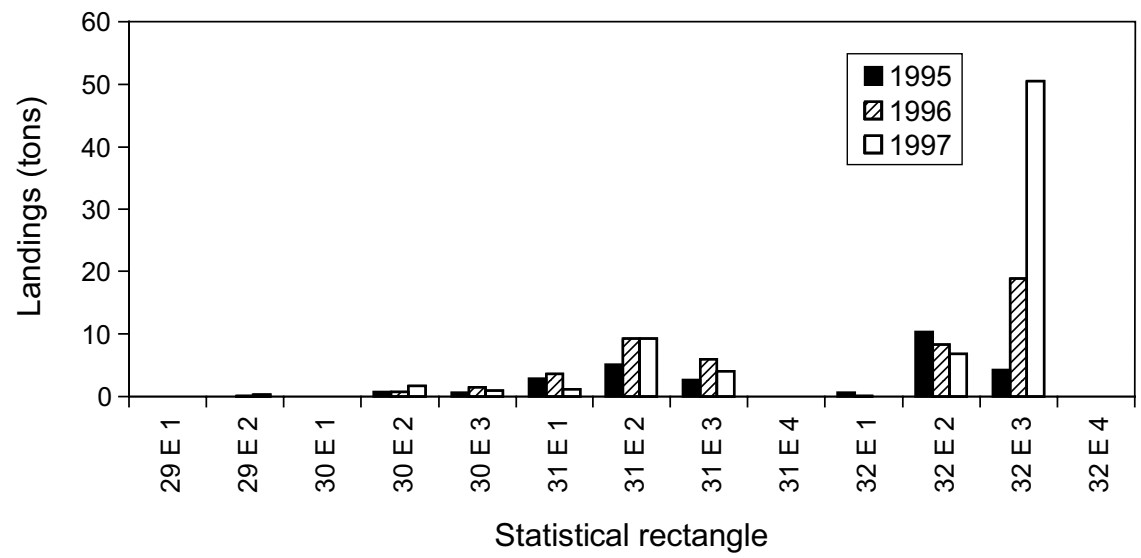

Fig. 8. Total ray landings by statistical rectangle for the Irish beam trawler fleet recording ray landings in ICES Division VIIg. Source: (Dept. of Communications, Marine and Natural Resources, Ireland). 


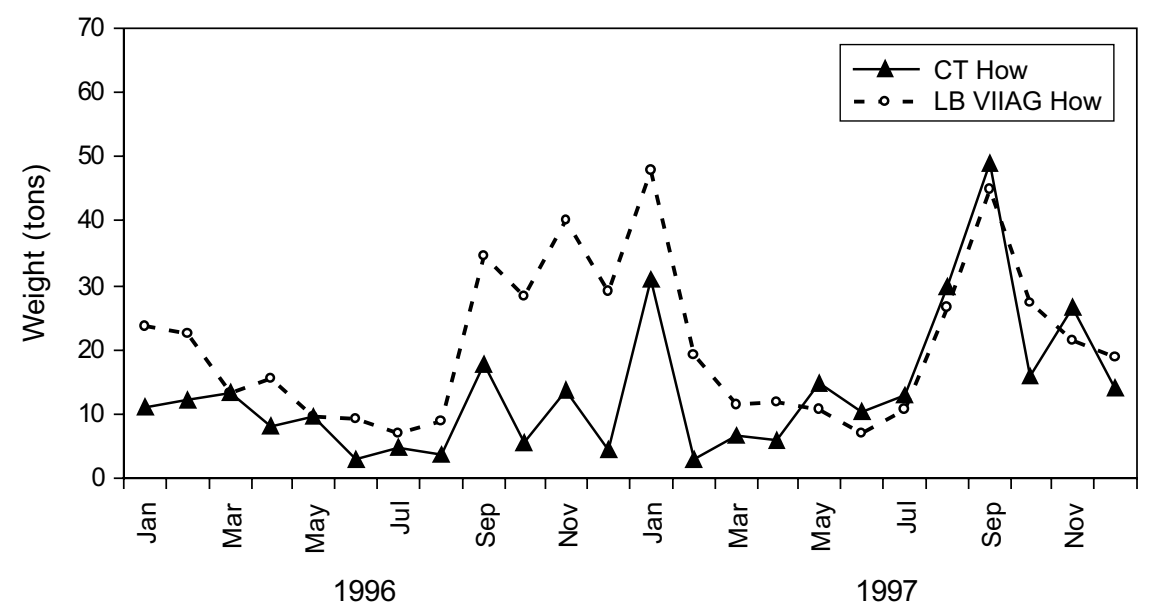

Fig. 9. Monthly ray landings from ICES Divisions VIIa and VIIg for Irish vessels landing at Howth (logbook data), plotted with commercial transactions data for the port. Source of logbook data: Dept. of Communications, Marine and Natural Resources, Ireland. Source of commercial transactions data; Sales Agents).

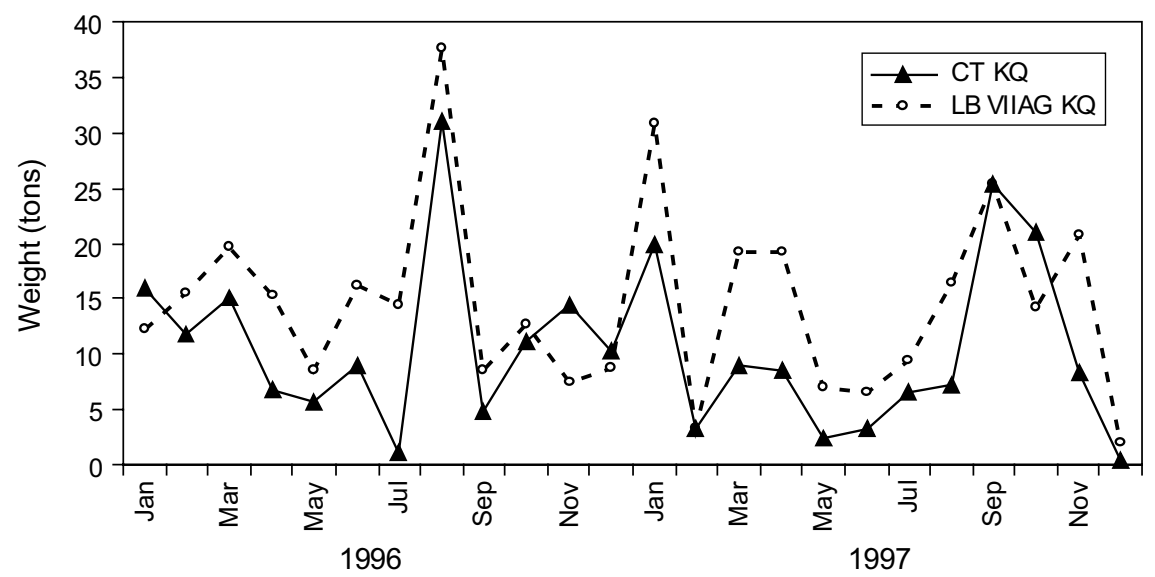

Fig. 10. Monthly ray landings from ICES Divisions VIIa and VIIg for Irish vessels landing at Kilmore Quay (logbook data), plotted with commercial transactions data for the port. Source of logbook data: Dept. of Communications, Marine and Natural Resources, Ireland. Source of commercial transactions data; Sales Agents).

1997, with $26 \%$ assigned as immature in comparison to over $75 \%$ of blonde and thornback rays (by number). For the two larger-sized species, the blonde and thornback rays, a higher proportion of the landings consisted of immature fish $(>75 \%)$ (Table 1).

Demographic analysis revealed that the most abundant species in the sampled landings, the cuckoo ray, yielded the highest population growth coefficient $(r=$ 0.255 ) (Table 2). The most commercially important species, the blonde ray, also exhibited a positive population growth coefficient $(r=0.224)$.

\section{Discussion}

The reliability of official logbook data is often considered questionable due to misreporting, particularly for species with restrictive quotas. In consequence, catch and effort data from such sources are seldom used in stock assessments of commercial species from the Irish Sea fishery (ICES, MS 1998). In this study, however, the close association evident between the landings contained in logbook returns and those from graded commercial data suggest that ray landings from logbook data are comparable with data from commercial sources. Anecdotal 


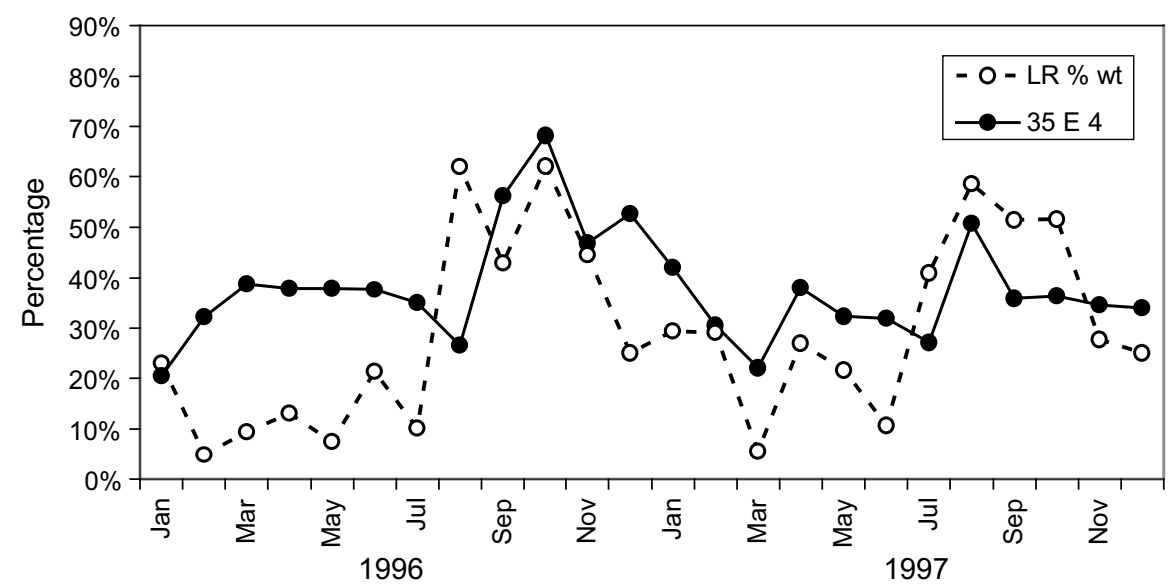

Fig. 11. Monthly effort of otter trawlers in statistical rectangle 35E4 expressed as a percent of total monthly otter trawler effort in ICES Division VIIa, plotted large ray grade landings at Howth expressed as a percentage of all ray landed at Howth in 1996 and 1997. (Effort data Source: Dept. of Communications, Marine and Natural Resources, Ireland. Commercial transactions data source: Sales Agents.).

evidence suggests that this can largely be attributed to the fact that rays are currently (2003) non-quota within the study locations, and as a result there is nothing to be gained in the falsification of returns. Analysis of logbook data by Statistical Rectangle confirmed the localization of the ray fishery described previously (Fahy, 1989; 1991; Hillis and Grainger, 1990), and in addition, the concentration of directed effort in one area within ICES Division VIIa (Statistical Rectangle 35E4). The ray fishing grounds within this area are known as the 'Peaks' where the large blonde ray is targeted towards the latter part of each year. This seasonality was particularly evident when the graded commercial landings and effort from the logbook data were plotted together. A clear association was apparent between the proportion of large ray landed and the directed effort within Statistical Rectangle 35E4. A more detailed description of the fishery including a the characterization of the fleet, seasonality of the effort, trends in graded landings and yield for both otter and beam trawlers is given in Gallagher (2000) for both ICES Divisions VIIa and VIIg.

The narrow age ranges and high mortality levels evident in this study are evidence that the commercial ray species in the Irish and northern Celtic Seas are heavily exploited. Armstrong and Briggs (1993) noted that as a result of intense exploitation most of the commercial teleost species in the Irish Sea have very restricted age ranges, (e.g. $60 \%$ of cod Gadus morhua is between 2 and 5 yrs, $67 \%$ of whiting Melanogrammus aeglefinus is between 2 and 4 yrs (Anon., 1999b)). This phenomenon is also evident in the commercial ray fishery where between $48 \%$ (male thornback ray) and $85 \%$ (male, spotted ray) of the rays landed are between 2 and 4 yrs old. Fahy (1989) also derived age distributions for the ray species in the western Irish Sea and although age ranges were similar, the relative shape of the distributions differed, with a much higher proportion of the commercial landings between $0 \mathrm{yrs}$ and 2 yrs $(50 \%$ blonde ray, $50 \%$ thornback ray, $22 \%$ cuckoo ray and $34 \%$ spotted ray) than was evident in this study (from $2.2 \%$ (female cuckoo ray) to $18.9 \%$ (male, blonde ray). These differences can possibly be attributed to inaccuracies in the ageing methodology used in Fahy's (1989) study, which led to overestimates of the length-at-age in the smaller size-classes, and a much larger proportion of the sampled landings allocated to the lower age-classes as a result (Gallagher, 2000). Analysis of the distributions in this study did, however, reveal that a high proportion of landings consisted of immature specimens, particularly in the larger-sized species ( $26 \%$ in male, spotted ray to $80 \%$ in male, thornback ray). This can be attributed to the fact that a high proportion of juvenile rays are retained by most trawled gears in the Irish Sea, and that no minimum landing size restrictions are in place for these species.

Total instantaneous mortality coefficients $(Z)$ varied between species and sex, with each of the smaller-sized species experiencing higher mortality than the larger-sized species. Fahy's (1989) mortality estimates for the combined sexes of these commercial ray species were lower (e.g. thornback ray 0.48 , spotted ray 0.74 ), but followed a similar trend to this study, with the smaller-sized species exhibiting higher mortality levels. It is unlikely that mortality levels would have been lower for the ray species during Fahy's (1989) study, as fishing effort of the demersal fleet during this period was comparable to this study. 

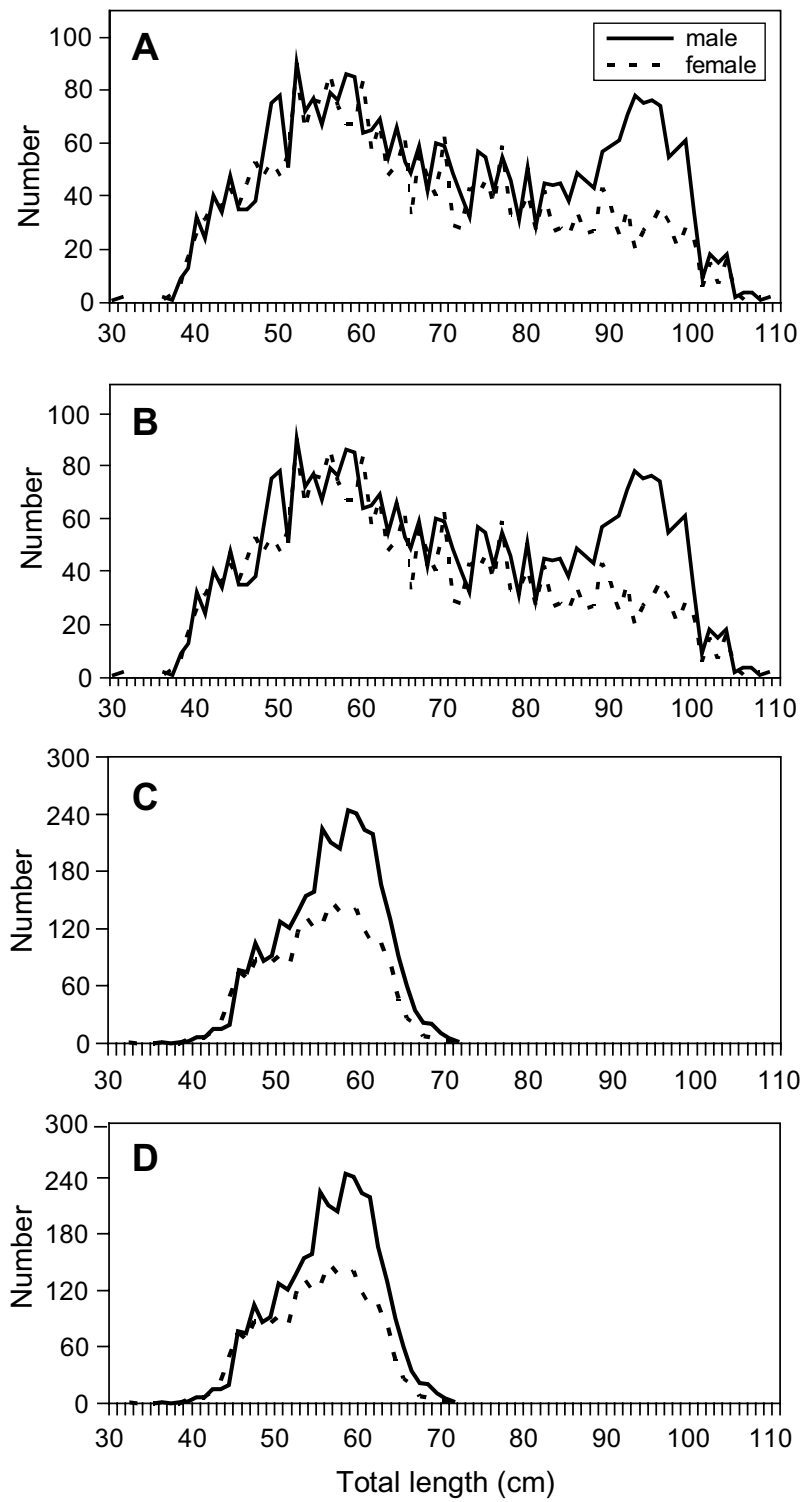

Fig. 12(a-d). Total length frequency distributions for male and female (A) blonde ray (B) thornback ray (C) spotted ray (D) cuckoo ray.

The lower mortality coefficients derived by Fahy (1989) may also be attributed to inaccurate age assessment of the smaller size-classes. Lower mortality coefficients were also derived by Ryland and Ajayi (1984) for the thornback ray (male; 0.56 , female; 0.27 ) and the spotted ray (male; 0.72, female; 0.48) in Carmarthen Bay, off the North Wales coast. It is possible that, owing to the sedentary nature of rays (Steven, 1936; Templeman, 1984), sub-populations of these species experience different mortalities due to differences in localized fishing effort. It is also probable, however, that, as with Fahy's (1989) study, inaccurate age assessment also confounds the estimates of Ryland and Ajayi's (1984) which has been alluded to previously (Brander and Palmer, 1985). It is worth noting that, as with this study, a similar trend of lower mortality estimates for females compared to males was evident for Ryland and Ajayi's (1984) study. This may be attributed to the fact rays periodically sexually segregate, and it is possible that males may be more exposed to the fishery at certain times of the year (Steven, 1936; Templeman, 1984).

There is little doubt that the commercial ray species in the Irish Sea continue to be adversely affected by intense exploitation, as the thornback ray, which was one of the 

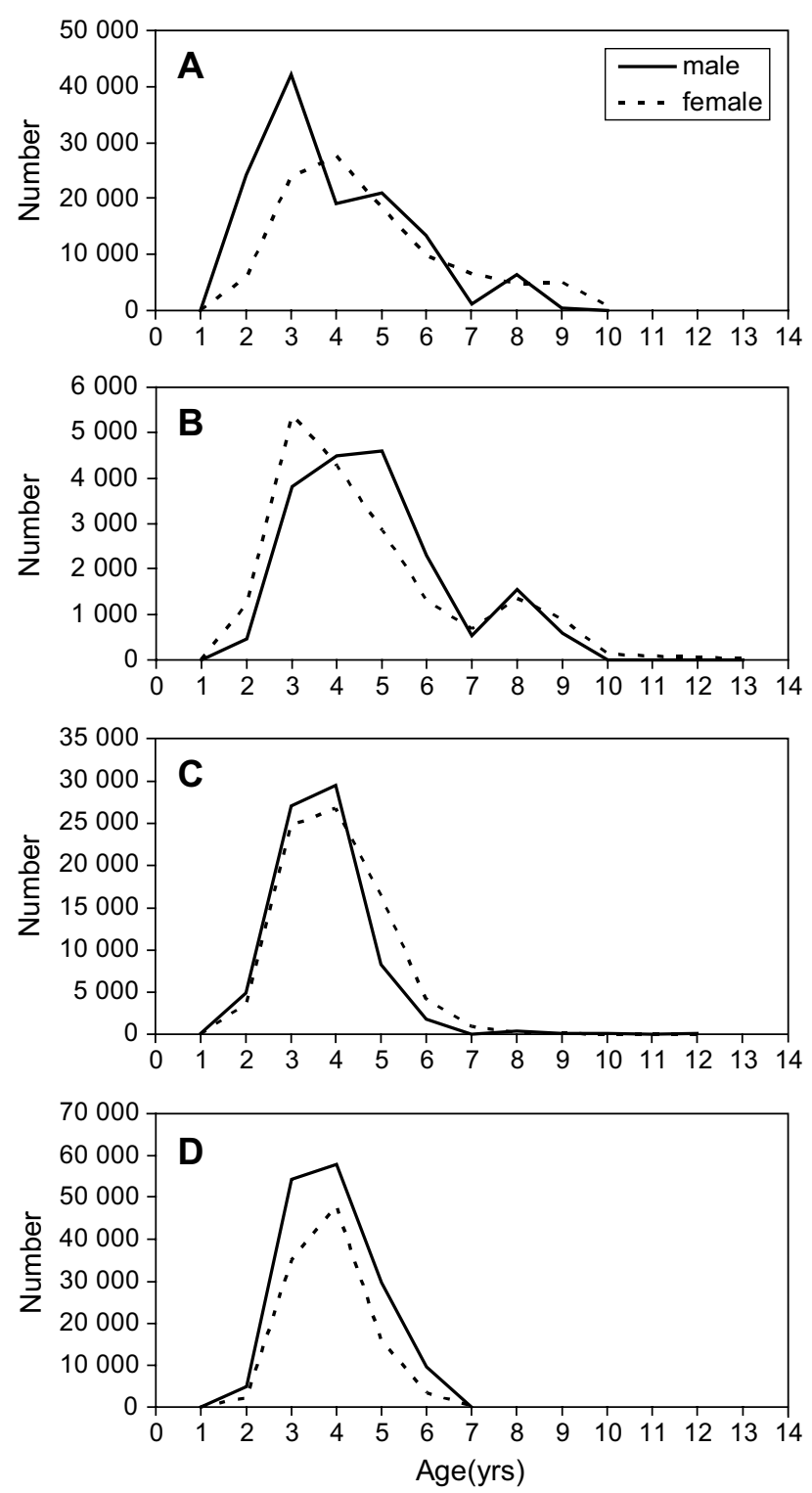

Fig. 13(a-d). Age distributions for the (A) blonde ray (B) thornback ray (C) spotted ray and (D) cuckoo ray, by sex, raised to the official landings (Dept. of the Marine and Natural Resources, Ireland) from ICES Div. VIIa and VIIg combined in 1997.

most abundant species sampled over a decade ago (Fahy, 1989), was the least abundant commercial species sampled in the landings in this study. In addition, contractions in the size distributions of the spotted and cuckoo ray were also evident (Gallagher, 2000). Despite these findings, the ray populations of the Irish and Celtic Seas have not shown the characteristic 'boom and bust' pattern evident in many exploited elasmobranch fisheries (Anderson, 1990). In addition, these populations have not shown the dramatic decline apparent for many of the demersal teleost species in the Irish Sea experiencing similar fishing mortality levels (ICES, MS 1998).

Demographic analysis revealed that although replacement mortality estimates were similar to total mortality estimates for most species landed, population growth was positive for all species except for the spotted ray $(r=$ $-0.045)$. A possible link between population growth and 
TABLE 1. Estimates of total numbers of rays in commercial landings, $\%$ immature, total instantaneous mortality coefficient $(Z)$, natural mortality $(M)$, and fishing mortality, by species, and sex from 1997. RB $\mathrm{m}=$ male blonde ray, $\mathrm{RB} \mathrm{f}=$ female blonde ray, $\mathrm{RC} \mathrm{m}=$ male thornback ray, $\mathrm{RC} \mathrm{f}=$ female thornback ray, $\mathrm{RM} \mathrm{m}=$ male spotted ray, $\mathrm{RM} \mathrm{f}=$ female spotted ray, $\mathrm{RN} \mathrm{m}=$ male cuckoo ray, $\mathrm{RN} \mathrm{f}=$ female cuckoo ray.

\begin{tabular}{lrcclcrc}
\hline \hline & Total No. & \% immature & Z & M & $F=(Z-M)$ & $Z^{\prime}$ \\
\hline RB m & 127825 & 74.770 & 0.762 & (ages 3-7 yrs) & 0.219 & 0.543 & \\
RB f & 102519 & 78.520 & 0.456 (ages 4-8 yrs) & 0.199 & 0.257 & 0.805 \\
RC m & 18302 & 79.070 & 0.713 (ages 4-7 yrs) & 0.228 & 0.485 & \\
RC f & 18250 & 77.570 & 0.633 (ages 4-7 yrs) & 0.166 & 0.467 & 0.710 \\
RM m & 72434 & 25.550 & 1.110 (ages 4-8 yrs) & 0.433 & 0.677 & \\
RM f & 75981 & 54.210 & 0.938 (ages 4-6 yrs) & 0.378 & 0.560 & 0.813 \\
RN m & 156592 & 56.600 & 0.899 (ages 4-6 yrs) & 0.420 & 0.479 & \\
RN f & 104526 & 58.810 & 0.795 (ages 3-6 yrs) & 0.313 & 0.482 & 0.961 \\
\hline
\end{tabular}

TABLE 2. Estimates of net reproductive rate $\left(R_{0}\right)$, generation time $(G)$, and instantaneous rate of increase $(r)$ for the blonde, thornback, spotted and cuckoo rays, based on demographic analyses.

\begin{tabular}{lccc}
\hline \hline & $R_{0}$ & $G$ & $r$ \\
\hline Blonde ray & 5.665 & 7.731 & 0.224 \\
Thornback ray & 2.441 & 7.139 & 0.125 \\
Spotted ray & 0.809 & 4.643 & -0.045 \\
Cuckoo ray & 3.412 & 4.823 & 0.255 \\
\hline
\end{tabular}

relative abundance of species in the sampled landings is evident as the two most abundant species, the cuckoo and blonde ray, both exhibited the highest population growth, whereas the least abundant species, the thornback ray, had the lowest positive population growth $(r=0.125)$. Input parameters for fecundity were derived from a recent study of the North Sea ray species (Walker and Hislop, 1998) for which estimates of the spotted ray were lower than other species. This influenced the population growth estimates derived for this species, in this study, and indeed, if other fecundity estimates are used (e.g. Ryland and Ajayi, 1984), positive population growth is derived for the spotted ray. This of course highlights the need for accurate input parameters when using this procedure. Despite the fact that the total mortality levels experienced by the commercial ray stocks in the North Sea are lower than those estimated in this study, demographic analysis revealed lower population growth for the North Sea species (e.g. spotted ray; $r=-0.13$, cuckoo ray; $r=0.002$ and thornback ray; $r=$ $-0.035)$. As the same fecundity estimates were used in both studies, the differences in population growth can be attributed to the higher age-at-maturity values used for the North Sea species (e.g. cuckoo ray $=7$ yrs) (Walker,
1999), which suggests that lower age-at-maturity increases resiliency to exploitation.

A number of other factors may also have contributed to the relative resilience of the ray populations in this heavily exploited environment. Although elasmobranchs are characteristically of low fecundity (Camhi et al., 1998), it has been suggested that rays, which are among the most fecund of this group (Holden, 1975), may have a more predictable, and at times, a higher yield-per-recruit than teleosts (Kulka and Miri, MS 2003). The increased growth and reduced age-at-maturity (Gallagher et al., in prep) evident, particularly for the smaller-sized species in the ray fishery, is of particular consequence in this regard (Hoenig and Gruber, 1990). Owing to the close stockrecruitment relationship evident for elasmobranchs, it is vitally important that a sufficient proportion of mature females can reproduce (Hoenig and Gruber, 1990). For the most abundant of the rays in this study (blonde and cuckoo ray), a lack of mature females in the sampled landings at certain times of the year (Gallagher, 2000), suggests that they may remain inshore after mating (Walker, 1999), and therefore are less vulnerable to exploitation. This is 
further evidenced in the lower total mortality coefficients derived in this study for females than for males. It has also been suggested that the depletion of many of the demersal teleost species has resulted in an increasing number of ecological niches becoming available to opportunist species. Rays are characteristically of this nature, and will readily occupy such available niches (Walker, 1999; Dulvy et al., 2000). Furthermore, rays are successful scavengers (Templeman, 1982), with a high proportion of their diet consisting of fish offal. As up to $20 \%$, by weight, of offal is discarded from a mature teleost fish (Anon., 1999b) during processing at sea the activities of demersal fishing vessels in the Irish Sea presents a readily available food resource for rays in this area. A further factor that may also enhance the survivability of rays is the suggestion that a proportion of the ray population occupies areas inaccessible to fishing, and that these 'refuges' provide a source of replenishment for more heavily exploited areas (Armstrong and Briggs, 1993; Walker et al., 1997; Casey and Myers, 1998). This is known to occur in the Irish Sea where an analysis of the spatial distribution of 'specimen' rays caught by recreational anglers, revealed a high proportion of these fish in certain parts of the Irish Sea (Fahy and O'Reilly, 1990).

Given that the ray stocks are an important component of the demersal fishery in the Irish Sea (Brander, 1988; Fahy, 1989), it is vitally important that a management strategy is implemented in order to conserve this resource. Although fishing effort may have declined over the past decade in the Irish Sea (ICES, MS 1998), the rapid depletion and heavy quota restrictions imposed on the main demersal teleost species may result in more vessels targeting rays, as has been observed in other fisheries (Atkinson, 1995; Kulka and Miri, MS 2003). This has already been observed (1998) in the area where a number of large beam trawlers have modified their gear to work in the "The Peaks" of the traditional ray fishery, targeting large blonde rays, particularly in inshore locations previously inaccessible to most trawled gear. In addition, several new whitefish vessels have recently joined the Irish fleet (Anon., 1999b), and their licensing agreement stipulates that $30 \%$ of their catch has to comprise nonquota species. Therefore it is envisaged that a number of these vessels will target rays in the Irish Sea under this licensing arrangement

It is evident from this study that the ray fishery of the Irish and Celtic Seas, in ICES areas VIIa and VIIg, can be assessed utilising appropriate sampling methods and data sources. The sustainability of this resource requires the implementation of appropriate management measures based on dedicated and directed objective assessments from such data sources. Failure to implement a suitable regime is likely to result in an unregulated increase in effort, the diminution of localized ray populations, the destruction of refuge areas and the ultimate commercial disappearance of this valuable resource.

\section{Acknowledgements}

We acknowledge those directly involved in the sampling, laboratory analysis and data collection, particularly Suzie Mitchell, Dave Foley, Jonathon Deane, Gareth McCarry and all staff in the Zoology Department, University of Dublin. Appreciation is also extended to those in the fishing industry who facilitated us in executing the various project tasks and making relevant data available. This study was funded under the Marine Operational Programme for Fisheries.

\section{References}

ANDERSON, E. D. 1990. Fishery models as applied to elasmobranch fisheries. In: Elasmobranchs as Living Resources: Advances in the Biology, Ecology, Systematics and the Status of the Fishery. NOAA Tech. Rep. NMFS. H. L. Pratt, S. H. Gruber and T. Taniuchi (eds.), U.S. Department of Commerce, Washington, p. 473-484.

ANON. 1999a. Case studies of the management of elasmobranch fisheries, Vol. 378. FAO Fish. Tech. Pap. R. Shotton (ed.), Rome, $490 \mathrm{p}$.

1999b. Ireland's marine and Coastal Areas and adjacent seas: an Environmental Assessment, 388 p.

ARMSTRONG, M. J., and R. P. BRIGGS. 1993. Role of fisheries science in management of Irish Sea fisheries. In: Managing Marine Fisheries: A case study of the Irish Sea, Liverpool University Press, Liverpool, p. 59-70.

ATKINSON, D. B. 1995. Skates in NAFO Divisions 3LNO and Subdivision 3Ps: a preliminary examination. Department of Fisheries and Oceans, Newfoundland, $10 \mathrm{p}$.

BRANDER, K. 1981. Disappearance of common skate Raia batis from Irish Sea. Nature, 290: 48-49.

1988. Multispecies fisheries of the Irish Sea. In: Fish Population Dynamics, (ed. J. A. Gulland). Wiley J. and Sons Ltd, $330 \mathrm{p}$.

BRANDER, K., and D. PALMER 1985. Growth rate of Raia clavata in the Northeast Irish Sea. Journal of the International Council for the Exploration of the Sea, 42: 125-128.

CAMHI, M., S. L. FOWLER, J. A. MUSICK, A. BRAUTIGAM, and S. V. FORDHAM. 1998. Sharks and their relatives-ecology and conservation. In: IUCN/SSC Shark Specialist Group, p. 39, IUCN, England, Switzerland and Cambridge, U.K. iv.

CASEY, J. M., and R. A. MYERS. 1998. Near extinction of a large widely distributed fish. Science, 281: 690-692.

DULVY, N.K., J. D. METCALFE, J. G. GLANVILLE, M. G. PAWSON, and J. D. REYNOLDS. 2000. Fishery stability, local extinctions, and shifts in community structure in skates. Conservation Biol., 14: 283-293.

FAHY, E. 1989. Fisheries for ray (Batoidei) in western statistical 
Area VIIa, investigated through the commercial catches I. Irish Fish. Investigations, Ser. B (Mar.), 34: 14 p.

1991. The southeastern ray Raja spp. fishery, with observations on the growth of rays in Irish waters and their commercial grading. Irish Fish. Investigations, Ser. B (Mar.) 37: $18 \mathrm{p}$.

FAHY, E., and R. O'REILLY. 1990. Distribution patterns of rays (Rajidae:Batoidei) in Irish waters. Irish Naturalists Journal, 23: 316-320.

GALLAGHER, M. J. 2000. The fisheries biology of commercial ray species from two geographically distinct regions. Ph.D. Thesis, Department of Zoology, University of Dublin, Trinity College, Dublin 2, Ireland.

GALLAGHER, M. J., C. P. NOLAN, and F. JEAL. 2004. Age, growth and maturity of the commercial ray species from the Irish Sea. Presented at the Symposium Elasmobranch Fisheries: Managing for sustainable use and biodiversity conservation. J. Northw. Atl. Fish. Sci., 35: 47-66 (this volume).

HILLIS, J. P., and R. J. R. GRAINGER. 1990. The species exploited. In: The Irish Sea: an Environmental Review. Part II. Exploitable Living Resources. T. A. Norton and A. J. Geffen (eds.), Liverpool University Press, p. 83-125.

HOENIG, J. M., and S. H. GRUBER. 1990. Life-history patterns in the elasmobranchs: implications for fisheries management. In: Elasmobranchs as Living Resources: Advances in the Biology, Ecology, Systematics, and the Status of the Fisheries, Vol. 90. NOAA Tech. Rep. NMFS. H. L. Pratt, S. H. Gruber and T. Taniuchi (eds.), U.S. Department of Commerce, Washington, p. 1-16.

HOLDEN, M. J. 1974. Problems in the rational exploitation of elasmobranch populations and some suggested solutions. In: Sea Fisheries Research. F. R. Harden Jones (ed.). Elk Science, London, 117-137.

HOLDEN, M. J. 1975. The fecundity of Raja clavata in British waters. ICES J. Cons., 36: 110-118.
HOLDEN, M. J. 1977. Elasmobranchs. In: Fish Population Dynamics. G. A. Gulland (ed.), p. 187-215.

ICES. MS 1998. Report of the Working Group on the Assessment of Northern Shelf Demersal Stocks. ICES C.M. Doc., No. 1998/ Assess:1, 375 p.

KULKA, D. W., and C. M. MIRI. MS 2003. The status of thorny skate (Amblyraja radiata Donovan, 1808) in NAFO Divisions $3 \mathrm{~L}, 3 \mathrm{~N}, 3 \mathrm{O}$ and Subdivision 3Ps. NAFO SCR Doc., No. 57, Serial No. N4875, 100 p.

PAULY, D. 1980. On the interrelationship between natural mortality, growth parameters, and mean environmental temperature in 175 fish stocks. ICES J. Cons., 39: 175-192.

RYLAND, J. S., and T. O. AJAYI. 1984. Growth and population dynamics of three Raja species (Batoidea) in Carmarthen Bay, British Isles. ICES J. Cons., 41: 111-120.

STEVEN, G. A. 1936. Migrations and growth of the thornback ray (Raia clavata L.). J. Mar. Bio. Assoc. U.K., 20(3): 605-614.

TEMPLEMAN, W. 1982. Stomach contents of the thorny skate, Raja radiata, from the Northwest Atlantic. J. Northw. Atl. Fish. Sci., 3: 123-126.

1984. Migrations of thorny skate, $R$. radiata, tagged in the Newfoundland area. J. Northw. Atl. Fish. Sci., 5: 55-63.

WALKER, P., G. HOWLETT, and R. MILLNER. 1997. Distribution, movement and stock structure of three ray species in the North Sea and eastern English Channel. ICES J. Mar. Sci., 54: 797-808.

WALKER, P. A. 1999. Fleeting images. Dynamics of North Sea ray populations, $\mathrm{PhD}$. Thesis. University of Amsterdam, Netherlands Institute for Sea Research, Texel. 142 p.

WALKER, P. A., and J. R. G. HISLOP. 1998. Sensitive skates or resilient rays? Spatial and temporal shifts in ray species composition in the central and north-western North Sea between 1930 and the present day. ICES J. Mar. Sci., 55: 392-402. 
